УДК 81'255.4

DOI https://doi.org/10.26661/2414-1135-2021-82-27

\title{
РОЗУМІННЯ ОРИГІНАЛУ ПЕРЕКЛАДУ ТА ФЕНОМЕНОЛОГІЯ ЯВИЩА
}

\author{
Межусва I. Ю. \\ кандидат педагогічних наук, дочент, \\ дочент кафедри перекладу \\ Приазовський державний технічний університет \\ вул. Університетська, 7, Маріуполь, Донецька область, Україна \\ orcid.org/0000-0002-8446-3568 \\ irina.mejueva.70@gmail.com
}

\author{
Ключові слова: технологія \\ перекладу, традиційно, \\ лінгвісти, подвійна \\ дія, еквівалентність, \\ адекватний вибір перекладу, \\ трансформачія, невербальні \\ умови.
}

Розглядперекладу як діалогу мов, культур, національних дискурсів дає змогу виявити унікальні феноменологічні особливості розуміння оригіналу в процесі перекладу. На відміну від загальногносеологічного явища розуміння мови перекладацьке розуміння тексту виключає надлишок суб'єктивного бачення, детермінованого установкою на споживача перекладу, допускає в діапазоні оцінки «якісний переклад» деяку варіативність із позиції повноти і глибини розуміння залежно від умов перекладу. Технологія перекладу традиційно розглядається лінгвістами як на подвійна дія, спрямована на забезпечення еквівалентності перекладу, яка включає в себе адекватний вибір перетворення перекладу за допомогою аналізу низки словесних і невербальних умов для перекладу і правильне застосування цієї техніки. Це формально точне, але непереконливе бачення перекладу здається безперспективним для створення технологій навчання перекладу, оскільки воно ігнорує ключовий інтелектуальний етап декодування процесу перекладу: вербальне сприйняття та розуміння вихідного тексту. Дослідження проблеми розуміння мови в процесі перекладу вимагає виділення його унікальних феноменологічних аспектів, які визначаються перекладацькою практикою. Виявлення виняткових особливостей розуміння вихідного тексту в процесі перекладу видається перспективним у рамках діалогічного методологічного підходу. Оскільки повне розуміння в людському спілкуванні здається неможливим, ми вважаємо за доцільне ввести поняття компетентної достатності розуміння вихідного тексту в процесі перекладу. Це розглядається як змінний результат розуміння 3 позиції його точності, повноти і глибини. Достатність поняття як критерій розуміння вимірюється кількісним співвідношенням усіх предметів, явищ і їх якостей у перекладеної версії і початковому тексті. Максимальна повнота розуміння тексту здається можливою в письмовому перекладі, але навряд чи можлива в усних формах перекладу. Глибину розуміння мови можна виміряти за допомогою ієрархічно упорядкованих рівнів сенсу тексту: зміст, загальний зміст, значення. Кожен із цих рівнів може позначати компетентну достатність розуміння вихідного тексту, яка залежить від форми перекладу та його функціонального комунікативного типу. Результати дослідження розкривають шляхи вдосконалення перекладацької практики як із позиції якості результатів перекладу, так і з позиції раціонального використання інтелектуальних резервів перекладача. 


\title{
UNDERSTANDING OF THE ORIGINAL IN TRANSLATION AND PHENOMENOLOGY OF THE PHENOMENON
}

\author{
Mezhyeva I. Yu. \\ Candidate of Pedagogical Science, Associate Professor, \\ Associate Professor at the Department of Translation \\ Pryazovskyi State Technical University \\ Universytetska str., 7, Mariupol, Donetsk region, Ukraine \\ orcid.org/0000-0002-8446-3568 \\ irina.mejueva.70@gmail.com
}

Key words: Translation technology, traditionally, linguists, a double act, equivalence, an adequate choice of translation, transformation, non-verbal conditions.
Consideration of translation as a dialogue of languages, cultures, national discourses reveals the unique phenomenological features of understanding the original in translation. In contrast to the general epistemological phenomenon, the understanding of the language, the translation understanding of the text excludes the excess of subjective vision, determined by the target of the translation on the consumer, allows some variation in the range of assessment of "high-quality translation" from the position of completeness and depth of understanding, depending on the translation conditions. Translation technology is traditionally viewed by linguists as a double act aimed at ensuring translation equivalence. It includes: an adequate choice of translation transformation by analyzing a number of verbal and non-verbal conditions for translation and the correct application of this technique. This formally accurate, but unconvincing vision of translation seems unpromising for the creation of translation learning technologies, since it ignores the key intellectual stage of decoding the translation process: verbal perception and understanding of the source text. The study of the problem of understanding the language in the process of translation requires the identification of its unique phenomenological aspects, which are determined by translation practice. Revealing the exceptional peculiarities of understanding the source text during translation seems promising in the framework of the dialogical methodological approach. Since full understanding in human communication seems impossible, we believe that it is possible to introduce the concept of a competent sufficiency of understanding of the original text in the translation process. This is seen as a variable outcome of understanding in terms of its accuracy, completeness, and depth. The sufficiency of a concept as a criterion for understanding is measured by the quantitative ratio of all objects, phenomena and their qualities in the translated version and in the original text. The maximum completeness of understanding the text seems to be possible in written translation, but hardly possible in oral forms of translation. The depth of understanding of the language can be measured using hierarchically ordered levels of meaning of the text: content, general meaning, idea. Each of these levels can indicate a competent sufficiency of understanding of the source text, which depends on the form of translation and its functional communicative type. The research results reveal the ways to improve translation practice both in terms of the quality of translation results and in terms of rational use of the translator's intellectual reserves.
Постановка проблеми. Проблема розуміння мови виступає ключовою в цілій низці напрямів наукового знання, пов'язаних із вивченням мови і мислення, мовної свідомості, вербально-когнітивних процесів людського пізнання. Будучи в позиції феноменології процесом когнітивним, явище розуміння давно викликає інтеpec дослідників-психологів. Однак проблематика розуміння мови (зокрема процесуальний аспект розуміння) так і не дістала належної уваги з боку лінгвістів-дослідників перекладу і перекладацької лінгводидактики.

Вербально-когнітивний процес розуміння мови під час перекладу ризикує взагалі залишитися непізнаною «річчю в собі», що розглядається виключно 3 позиції лінгвістичної теорії 
перекладу. При цьому остання переконана у своїй самодостатності, але не володіючи належним інструментарієм і технологією розтину суті інтелектуальних процесів, позиціонує консерватизм у своєму самовизначенні і автономному існуванні, сліпо дотримуючись твердження Р. Якобсона (більш ніж півстолітньої давності) про примата знаходження перекладу «під невсипущим наглядом мовознавства» [1, с. 233].

Мета і завдання статті полягає у вивченні явища розуміння оригіналу в процесі перекладу: до питання про феноменологію явища близькості i співвіднесеності тексту оригіналу і тексту перекладу за критеріями адекватності та еквівалентності. Це зіставлення виявляє закономірності перекладацького процесу, знання яких і вміння їх використовувати формують перекладацьку компетенцію.

Технологія перекладу, репрезентована лінгвістикою перекладу, є не що інше як свого роду двоопераційна дія щодо забезпечення перекладацької відповідності:

а) адекватний вибір перекладацького прийому (трансформації) через аналіз перекладачем низки мовних і немовних аспектів, ситуативних і контекстуальних умов перекладу;

б) грамотне застосування перекладацького прийому (трансформації).

Предмет та об'скт дослідження. Предметом дослідження є когнітологія в загальному феноменологічному плані та проблема розуміння мови в контексті перекладацької теорії і лінгводидактики. Спробуємо розкрити особливі сторони цього явища, які своєрідно i, можливо, навіть допустимо суперечать загальнофеноменологічним особливостям розуміння мови, що детерміновано умовами перекладацької діяльності. Об'єктом дослідження виступають переклад та виявлення унікально феноменологічних особливостей перекладацького розуміння з позиції діалогічної методології (закладеної свого часу М.М. Бахтіним).

Виклад основного матеріалу дослідження. Лінгвістика перекладу наполегливо наголошує на своєму баченні процесу перекладу як деякого «перетікання» сенсу з однієї мовної оболонки в іншу. Наприклад, прийом експлікації, або описового перекладу, дефінується як лексико-граматична трансформація, при якій лексична одиниця іноземної мови замінюється словосполученням, експлікуючи іï значення, тобто дає більш-менш повне пояснення або визначення цього значення мовою перекладу. Нібито знання мовних відповідностей для конкретної пари мов здатне забезпечити оптимальну адекватність цих мовних оболонок вербалізації тієї ж думки різними мовами.

Формально правильний, але, по суті, поверхневий погляд на переклад здається безперспективним для формування перекладацької лінгводидак- тичної технології, яка нині так і не представлена як теоретично і методично структурована і практично апробована лінгвістична освітня практика. I одним із суттєвих упущень розгляду технології перекладу 3 позиції лінгвістики перекладу є ігнорування як мінімум одного проміжного інтелектуального етапу перекладу - етапу декодування: сприйняття і розуміння того чи іншого сегмента тексту оригіналу (лексичної одиниці, речення, фрагмента тексту), який може супроводжуватися додатковими проміжними етапами в разі труднощів декодування на будь-якому рівні ідентифікації мовного сигналу.

Допущення розгляду категорій «семантика» вербальної одиниці і «зміст» вербального повідомлення як лінгвістичних (хоча і це дискусійно) при безспірному зарахуванні поняття «сенс» до явищ виключно когнітивних, психологічних, навіть у разі консервативного ставлення до питання не дозволяє виключити свідомість розуміючого суб'єкта 3 процесу розуміння мови i, відповідно, перекладу. Розуміння оригіналу в процесі перекладу можна визначити в стилі словесних формулювань як процес «осмислення значення» процес трансформації смислового змісту деякого знаково-символічно закодованого повідомлення 3 мови фонографічних символів мовою інтелекту. Мовотворення як наступний етап перекладацької діяльності передбачає зворотну операцію: вербалізацію осмисленого змісту за допомогою символів іншої природної мови. В.П. Зінченко називає цей етап процесом «визначення сенсу» [2, с. 274]. Все це свідчить про принципову можливість етапу «визначення сенсу» тільки за умови успішності етапу «визначення значення».

Можна стверджувати, що саме розуміння оригіналу (часткове або повне нерозуміння) детермінує адекватність/неадекватність перекладу (як результату) і значною мірою визначає рівень його еквівалентності.

Інтерпретованість будь-якого тексту, що розглядається як універсальна властивість мовного творення і критерій його віднесення до розряду текстів, зумовлює суб' єктивність розуміння повідомлення - переломлення змісту промови крізь призму індивідуально-морального i соціокультурного досвіду особистості, яка сприймає текст. Перекладацьке розуміння спирається на фокус об’єктивації і раціоналізації споглядання не всередині, а поза особистістю, яка сприймає (перекладача). Подолання надмірності суб'єктивного бачення в процесі перекладу можливе завдяки пізнанню, яке формує єдиний, загальнозначущий і тотожний собі світ, мінімально атрибутований до єдності «місця в бутті» особистості, яка сприймає.

Розуміння у процесі перекладу є найбільш яскравим прикладом i безпосереднім доказом 
висунутої свого часу М.М. Бахтіним гіпотези про певну властивість діалогічності розуміння, яку нині популяризують у контексті поліцентричного підходу до дослідження комунікації (що прийшов на зміну моноцентричному підходу), який ураховує рівноправність адресанта й адресата на комунікативній осі [3, с. 245].

У філософській концепції діалогу М.М. Бахтіна, що заклала основи діалектики діалогіки, суб' єктивність сприйняття цілого зумовлена унікальністю місця спостерігача, одиничністю «його місця в бутті», що провокує завжди наявний щодо того, хто сприймає «надлишок суб' єктивного бачення і знання». I, якщо за твердженням М.М. Бахтіна, «естетичне споглядання і етичний вчинок не можуть відволіктися від конкретної єдності місця в бутті, яке займає суб'єкт цієї дії і художнього споглядання» [3, с. 259], то перекладацьке розуміння спирається на фокус об'єктивації і раціоналізації споглядання не всередині, а поза особистістю, яка сприймає (перекладача).

Подолання надмірності суб'єктивного бачення в процесі перекладу можливе завдяки пізнанню, яке формує єдиний, загальнозначущий і тотожний собі світ, мінімально атрибутований до єдності «місця в бутті» особистості, яка сприймає.

Таке пізнання висуває підвищені вимоги до знань і нелінгвістичних знань перекладача. Надалі в термінах діалогічності лінгвістичної комунікації М.М. Бахтіна розуміння мови $є$ «співтворчістю тих, хто розуміє» - адресанта і адресата, результат зіткнення двох смислів, що дає змогу актуалізувати «потенційну нескінченність актуального сенсу». При цьому сам М.М. Бахтін допускає відволікання від діалогічної боротьби двох смислів і наявність Позиції третього у випадках «вивчення мови і різних областей ідеологічної творчості» [3, с. 268].

У контексті перекладацької діяльності діалогічність розуміння як процес і результат першого етапу перекладання передбачає, на нашу думку, установку на споживача перекладу: розуміння 3 урахуванням менталітету, ціннісних установок, домінант лінгвокультури адресата перекладу, комунікативної ситуації перекладу, а також специфіки мовного кодування світу, але ніяк не розуміючого суб'єкта - перекладача, посередника в спілкуванні. Установка на споживача перекладу закономірно потребує від перекладача (третього на комунікативній осі) наступної за розумінням оригіналу лінгвопрагматичної адаптації перекладу $\mathrm{i}$, по суті, забезпечує можливість цієї адаптації, бо розуміння передує і забезпечує дію. Лінгвопрагматичну адаптацію перекладу можна визначити як «міжмовне для конкретної пари мов узгодження парадигм мовних відповідностей із позиції прагматики слів, семантики текстового оточення, сенсу мовних висловлювань - всіх тих аспектів мовного кодування, викликаних специфікою національної концептуалізації світу і іiі закріплення в конвенціональних знаках». Все це являє собою ні що інше, як діалог - «діалог мов, культур, діалог національних дискурсів та інституційних форм спілкування», - і постулює діалогічність перекладацького розуміння [4, с. 259].

$\mathrm{y}$ концепції діалогізму деяких вчених мова трактується як реалізована в конкретних мовних висловлюваннях (інтерактивна одиниця мовного спілкування), межі яких визначені зміною мовних суб'єктів. Останні «не піддаються граматикалізації і зберігають свою специфічну природу, принципово відмінну від [природи] відношень між словами і реченнями (i іншими мовними одиницями - словосполученнями і т.п.) всередині висловлювання» [3, с. 251]. Тим самим розуміння мови в його загальнофеноменологічному плані реалізується не в лінгвістичному контексті (потоці речень і слів), а в контексті жанрового спілкування (мовному потоці висловлювань) - «семантичному ландшафті» [5, с. 12]. Настільки активно відхилений лінгвістичний (граматикалізований) контекст розуміння мови видається дуже доречним у перекладацькому розумінні: мовний потік у процесі перекладу потребує розчленування не тільки i не стільки на висловлювання (одиниці мовного спілкування), скільки на пропозиції, словосполучення, слова (одиниці мови) - лінгвістичні (граматикалізовані) форми як конвенціональні і еквівалентні собі сигнали.

Неможливо не визнати важливість розуміння оригіналу під час перекладу. Подібно до неможливості в людському спілкуванні стовідсоткового розуміння [2, с. 176], в перекладі неможлива стовідсотково достовірна передача оригіналу, оскільки переклад - подвійно суб'єктивне явище, двічі переломлюється через свідомість перекладача-посередника: по-перше, в процесі розуміння оригіналу, по-друге, у процесі вербалізації інформації мовою перекладу. Це дозволяє нам запропонувати поняття якісної достатності перекладацького розуміння як потенційно вимірюваний, але варіативний показник оцінки розуміння за сумарної релевантності критеріїв адекватності, повноти і глибини.

Для визначення категорії достатності розуміння оригіналу в перекладі і встановлення діапазону варіативності якості розуміння пропонуємо авторську теорію рівнів розуміння при збереженні принципових категоріальних критеріїв оцінки результативності розуміння: точності, повноти і глибини. Точність розуміння оригіналу в процесі перекладу пропонуємо визначити як вимірювану ступенем адекватності сприйняття в оригінальному повідомленні низки ключових інформативно значущих елементів, таких як прецизійна інформація: літерна (топоніми, назви організацій, фірм, корпорацій, 
місяців і днів тижня, назви торгових марок і брендів продукції), цифрова (дати, формули, числа, одиниці величин і заходів), позиційно-номінативна.

Висновки i перспективи подальших розробок. Можна стверджувати, що незалежно від форми перекладу (письмовий/усний) і виду перекладу (виділеного на підставі комунікативної та стилістичної спрямованості тексту) точність розуміння оригіналу як стовідсотково адекватна передача прецизійної інформації не має ступенів свободи. Точність виступає єдиним і неваріативним критерієм якості розуміння і перекладу. Повнота перекладацького розуміння оригіналу виміряна через кількісне зіставлення масиву предметних значень, присутніх у тексті оригіналу та переданих у тексті перекладу. Це $є$ розуміння в полі предметних значень, матеріально втілене в повноті фіксації в перекладі всіх об'єктів, явищ і їх ознак, зазначених в оригіналі. Варіативність цього критерію детермінується, на нашу думку, формою перекладу (письмовий/усний). Оптимальне розуміння оригіналу, можливе в процесі письмового перекладу, недосяжне в умовах усного перекладу. Завжди актуальна формально-мовна невідповідність усного мовлення на різних мовах (нерівнозначності не тільки словесної, але і складової величини мови), що своєю чергою зумовлює і відмінність у семантичній щільності мови, а також дефіцит часу, об'єктивний ліміт швидкості мовно-мисленнєвих операцій і неминуче присутнє зниження ступеня контролю перекладача - все це виправдовує спотворення сприйняття матеріалу в межах, допустимих поняттям «якісний переклад» [6, с. 109].

Найчастіше спотворення передачі інформації фіксується в деякому порушенні послідовності інформаційних одиниць і мовної компресії. Достатність розуміння оригіналу в процесі інформаційного перекладу (науково-технічний, військовий, медичний і т.д.) цілком може обмежуватися рівнем загального змісту тексту, що не виключає ситуативної необхідності з'ясування і прихованого сенсу завдяки нині фіксованій активній метафоризації мас-медійного, економічного і політичного дискурсів. Сприйняття мови перекладачем-синхроністом реалізується як горизонтально спрямований рух думки «уздовж» тексту, що знаменує розуміння на рівні змісту, чого цілком достатньо з урахуванням умов синхронної двомовності.

Можна вважати, що зазначені варіанти ступенів достатності перекладацького розуміння оригіналу для різних форм і видів перекладу наочно демонструють особливості діалогізму розуміння мови в процесі перекладу, раніше визначеного нами як установка на споживача перекладу. Таким чином, виділені нами з позиції діалектики діалогіки унікальні феноменологічні особливості перекладацького розуміння полягають: a) в опорі розуміння на пізнання і точку об'єктивації сприйняття поза себе, втіленні перекладачем позиції третього на комунікативної вісі, що дає змогу подолати надлишок суб' єктивного бачення;

б) у діалогічності розуміння як установці на споживача перекладу в контексті діалогу не особистостей, а мов, культур, національних дискурсів;

в) у реалізації розуміння оригіналу за принципом знакового атомізму, тобто в граматикалізованому контексті конвенціональних одиниць i мовних одиниць, що володіють нормативною тотожністю;

г) у варіативності якості розуміння 3 позиції достатності в різних мовних і немовних, ситуативних і контекстуальних умовах перекладу.

Результати цього теоретичного дослідження виступають психологічним обгрунтуванням розробки ефективних технологій перекладацької лінгводидактики, що дасть змогу сформувати перцептивну готовність майбутнього перекладача як комплекс диференційованих відповідно до видів і форм перекладу умінь розуміння, що забезпечують достатній і ефективний перекладацький діалог і перекладацьку ерудицію.

\section{ЛITEPATУPA}

1. Jakobson R. On Linguistic Aspects of Translation. In: On Translation. Cambridge: Harvard University Press, 1959, pp. 232-239.

2. Зинченко В.П. Психологические основы педагогики (Психолого-педагогические основы построения системы развивающего обучения Д.Б. Эльконина - В.В. Давыдова) : Учебное пособие. Москва : Гардарики, 2002. 432 с.

3. Бахтин М.M. Проблема речевых жанров. Эстетика словесного творчества / сост. С.Г. Бочаров. Москва, 1979. С. 237-280.

4. Уланович О.И. Феноменология двуязычия: специфика формирования в искусственной языковой среде. Актуальные проблемы гуманитарного образования : материалы Интернет-конференции, 20-28 февраля 2014 г. Минск, 2014. С. 256-260.

5. Шоттер Дж. М.М. Бахтин и Л.С. Выготский: интериоризация как «феномен границы». Вопросы психологии. 1996, №6. С. 107-117.

6. Уланович О.И. Психолингвистика : учебное пособие. Минск : изд-во Гривцова 2010. 240 с.

\section{REFERENCES}

1. Jakobson R. On Linguistic Aspects of Translation. In: On Translation. Cambridge: Harvard University Press, 1959. Pp. 232-239.

2. Zinchenko V.P. (2002) Psychological foundations of pedagogy [Psikhologicheskie osnovy pedagogiki]. Moscow: Gardariki Publ. 
3. Bakhtin M.M. (1979) Aesthetics of verbal creativity [Problema rechevykh zhanrov. Estetika slovesnogo tvorchestva / sost. S.H. Bocharov. Moscow : Iskusstvo Publ.

4. Ulanovich O.I. (2014) Phenomenology of bilingualism: the specificity of the formation of an artificial language environment [Fenomenologiya dvuyazychiya: spetsifika formirovaniya $\mathrm{v}$ iskusstvennoy yazykovoy srede]. Actual problems of humanitarian development: materials of the Internet conference,
March 20-28. 2014 p. Minsk : NTI-VINITI : Obshchestvennye nauki Publ, Pp. 256-260.

5. Shotter J. (1996) M. M. Bakhtin i L. S. Vygotskiy: internalization as "a phenomenon of the border" [M.M. Bakhtin i L.S. Vyhotskyy: interioryzatsiya kak «fenomen hranytsi»]. Voprosy psikhologii. Vol. 6. Pp. 107-117.

6. Ulanovich O.I. (2010) Psycholinguistics [Psikholingvistika: ucheb. posobiye]. Minsk: Izd-vo Grevtsova Publ. 240 p. 